The Afghanistan Wars 
Also by William Maley

THE AUSTRALIAN POLITICAL SYSTEM (with David W.

Lovell, lan McAllister and Chandran Kukathas)

DEALING WITH MINES: Strategies for Peacekeepers, Aid

Agencies and the International Community (editor)

THE FOREIGN POLICY OF THE TALIBAN

FUNDAMENTALISM REBORN? AFGHANISTAN AND THE

TALIBAN (editor)

POLITICAL ORDER IN POST-COMMUNIST AFGHANISTAN

(with Fazel Haq Saikal)

REGIME CHANGE IN AFGHANISTAN: Foreign Intervention

and the Politics of Legitimacy (with Amin Saikal)

RUSSIA IN SEARCH OF ITS FUTURE (with Amin Saikal, co-editor)

SHELTERS FROM THE STORM: Developments in International Humanitarian Law (editor)

THE SOVIET WITHDRAWAL FROM AFGHANISTAN (with

Amin Saikal, co-editor)

THE THEORY OF POLITICS: An Australian Perspective (with Chandran Kukathas and David W. Lovell)

THE TRANSITION FROM SOCIALISM: State and Civil Society in the USSR (with Chandran Kukathas and David W. Lovell, co-editors) 


\section{The Afghanistan Wars}

William Maley 


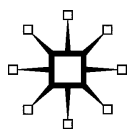

(C) William Maley 2002

All rights reserved. No reproduction, copy or transmission of this publication may be made without written permission.

No paragraph of this publication may be reproduced, copied or transmitted save with written permission or in accordance with the provisions of the Copyright, Designs and Patents Act 1988, or under the terms of any licence permitting limited copying issued by the Copyright Licensing Agency, 90 Tottenham Court Road, London W1T 4LP.

Any person who does any unauthorised act in relation to this publication may be liable to criminal prosecution and civil claims for damages.

The author has asserted his right to be identified as the author of this work in accordance with the Copyright, Designs and Patents Act 1988.

First published 2002 by

PALGRAVE MACMILLAN

Houndmills, Basingstoke, Hampshire RG21 6XS and

175 Fifth Avenue, New York, N.Y. 10010

Companies and representatives throughout the world

PALGRAVE MACMILLAN is the global academic imprint of the Palgrave Macmillan division of St. Martin's Press, LLC and of Palgrave Macmillan Ltd. Macmillan ${ }^{\circledR}$ is a registered trademark in the United States, United Kingdom and other countries. Palgrave is a registered trademark in the European Union and other countries.

ISBN 978-0-333-80290-8 hardcover

ISBN 978-0-333-80291-5 ISBN 978-1-4039-1840-6 (eBook)

DOI 10.1007/978-1-4039-1840-6

This book is printed on paper suitable for recycling and made from fully managed and sustained forest sources.

A catalog record for this book is available from the Library of Congress Library of Congress Cataloging-in-Publication Data

Maley, William, 1957-

The Afghanisthan wars / Willam Maley.

p. $\mathrm{cm}$.

Includes bibliographical references and index.

ISBN 978-0-333-80290-8-ISBN 978-0-333-80291-5 (pbk.)

1. Afghanistan-History-Soviet occupation, 1979-1989.

2. Afghanistan-History-1989-2001. 3. Afghanistan-History, Military-20th century. I. Title.

DS371.2 .M342 2002

958.104'5-dc21

2002070642

$\begin{array}{rrrrrrrrrr}10 & 9 & 8 & 7 & 6 & 5 & 4 & 3 & 2 & 1 \\ 11 & 10 & 09 & 08 & 07 & 06 & 05 & 04 & 03 & 02\end{array}$


For my mother, Jean Maley, and in Memory of my father, Raymond Maley, CVO 


\section{Contents}

Acknowledgements

viii

Map

$\mathrm{X}$

Introduction 1

1 The Road to War 5

2 Soviet Strategy, Tactics, and Dilemmas 37

3 The Development of Afghan Resistance 57

4 The Karmal Period, 1979-1986 85

5 The Najibullah-Gorbachev Period, 1986-1989 108

6 The Road to Soviet Withdrawal 126

7 Consequences of the Soviet-Afghan War 153

8 The Interregnum of Najibullah, 1989-1992 168

9 The Rise and Fall of the Rabbani Government, 1992-1996 194

10 The Rise and Rule of the Taliban, 1994-2001 218

11 The Fall of the Taliban 251

References $\quad 284$

$\begin{array}{ll}\text { Index } & 322\end{array}$ 


\section{Acknowledgements}

Afghanistan is a remarkable country, almost as remarkable as its peoples. Over the course of the journey of many years that led to the writing of this book, countless Afghans have helped me in one way or another. Yet remarkable too is the large community of scholars and aid workers that coalesced around Afghanistan. The late Louis Dupree warned me that once Afghanistan got into your blood, you could never be rid of it. In this, as in so many other things, he was right.

It might therefore seem invidious to identify individuals for particular gratitude, but to omit the following names would be more than churlish, given the extent to which my own thinking has been shaped by the insights of those with whom I have come into contact. Here, I can only list them with my thanks: Nasiba Akram, A. Rasul Amin, Sayed Aqa, Anthony and Ruth Arnold, Paul Bonard, Pippa Bradford, Henry S. Bradsher, Rob Breen, Alan Brimelow, Geoff Brooks, Ian Bullpitt, Grahame Carroll, Pierre Centlivres, Micheline Centlivres-Demont, Roy Clogstoun, Pamela Collett, Rupert Colville, Umer Daudzai, Anthony Davis, Tahsin Disbudak, Gilles Dorronsoro, Nancy Hatch Dupree, Mohammed Eshaq, Abbas Faiz, A. G. Ravan Farhadi, Patricia Garcia, Bernt Glatzer, Frédéric Grare, Thomas Gurtner, Ejaz Haider, Habib Hala, Nick Hordern, David C. Isby, Kiyotaka Kawabata, Masood Khalili, Bruce Koepke, Christopher Kremmer, Najibullah Lafraie, Geoff Leach, Jonathan Lee, Conny Lenneberg, Jolyon Leslie, Jens Lüneburg, Citha Maass, Richard Mackenzie, Spozhmai Maiwandi, Ian and Margaret Mansfield, Nabi Misdaq, Sayed Askar Mousavi, Kabir Osman, Sayed Padshah, Mervyn Patterson, Sue Pennell, John Renninger, Engineer Abdul Rahim, Fahim Rahimyar, Samantha Reynolds, Haider Reza, Hilary Riggs, Olivier Roy, Abdul Rahman Sahak, Fazel Haq Saikal, Kassem Saikal, Mahmoud Saikal, Maliha Saikal, Nadir Saikal, Nouria Salehi, 
Susanne Schmeidl, Ralph Seccombe, Nazif Shahrani, Soliman Stanekzai, Barry Stride, Hiroshi Takahashi, Fiona Terry, Andrew Tesoriere, Ramesh Thakur, Darka Topali, Rosemary Trott, Bill Van Ree, Patrick Vial, Marvin G. Weinbaum, Steven Wolfson, and Daoud Yaqub

There are four more specialists on Afghanistan to whom my debt is very large indeed. Ashraf Ghani, Ahmed Rashid, Barnett R. Rubin, and I have been sharing thoughts about Afghanistan for a considerable period. Through the good offices of Lakhdar Brahimi and Francesc Vendrell, we were able to meet as a group at different times in New York, Oslo, and Berlin, and it has been a pleasure as well as a privilege to share their company. And Amin Saikal, a dear friend of many years' standing, has been a constant source of support, information, and critical comment, almost on a daily basis. I simply don't know how to thank him, but I'm sure he will tell me!

I am most grateful to Beverley Lincoln and Sue Moss of the School of Politics at the University of New South Wales for their assistance in the production of this book. Penny Simmons edited the manuscript swiftly and with great skill. Finally, I must thank Terka Acton of Palgrave for many things, not least her near-saintly patience.

William Maley Canberra, April 2002 

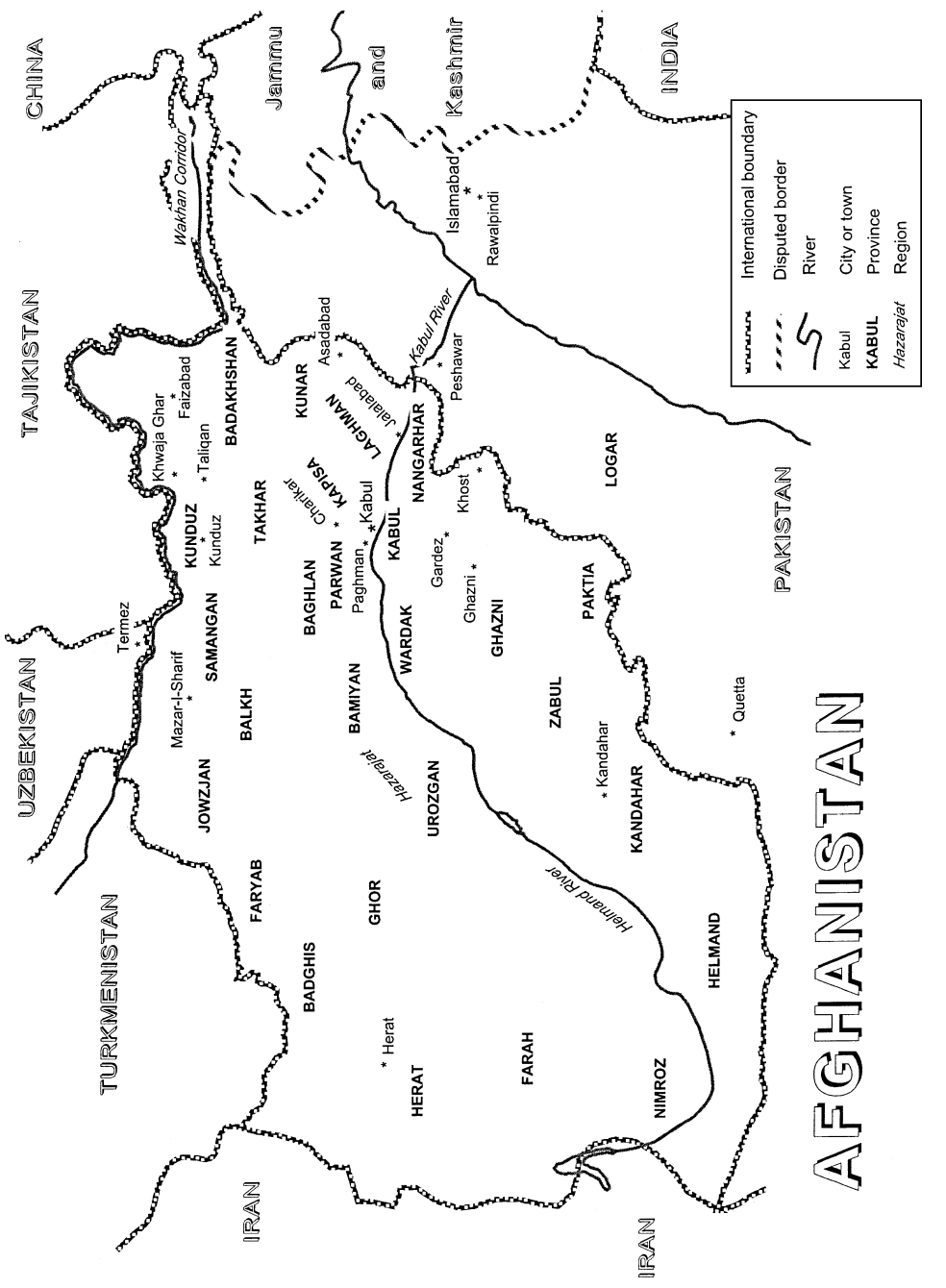